\title{
Meta-Analysis: The Effect of Neuropatic Complications and Depression Commorbidity on the Quality of Life of Patients with Type 2 Diabetes
}

\author{
Rofana Aghniya'), Bhisma Murti'), Didik Gunawan Tamtomo²) \\ 1)Masters Program in Public Health, Universitas Sebelas Maret \\ ${ }^{2)}$ Faculty of Medicine, Universitas Sebelas Maret
}

\section{ABSTRACT}

Background: Diabetes mellitus is a metabolic disease that results from insulin insufficiency and often causes complications. DM patients are prone to depression. Depression is one aspect that affects the quality of life. Measuring the quality of life in DM patients is done as a measure of the success of the intervention. This study aims to estimate the influence of neuropathic complications and comorbid depression on the quality of life of type $2 \mathrm{DM}$ patients based on the results of previous studies.

Subjects and Method: Meta-analysis studies and systematic studies were applied to this research with electronic data sources PubMed, ProQuest, Science Direct, Scopus, Spinger Link and Google Scholar. The key words used were as follows: Comorbidity depression and DM, depression and quality of life and DM and cross sectional study, neuropathy and quality of life and DM and adjusted odd ratio, neuropathy or diabetes, depression or quality of life or DM or adjusted. odd ratio. The article used is a fulltext article with a cross-sectional study design and the results are reported in adjusted odds ratio (aOR). Articles were analyzed using the Review Manager 5.3 application with fixed effect models.

Results: Fifteen articles reviewed in this study originated from 5 continents. 6 studies came from the Asian continent (Japan, Iran, Singapore, Korea, China and Nepal), 4 studies from the European continent (Norway and 3 United Kingdom), 2 studies from the African continent (Uganda and Nigeria), 2 studies from the North American continent (Brazil) and 1 study from the continent of South America (USA). The results of the forest plot interpretation showed that patients with type 2 diabetes mellitus with neuropathy complications had 0.78 times the chance of having a good quality of life compared to type $2 \mathrm{DM}$ patients without neuropathic complications $(\mathrm{aOR}=0.78 ; 95 \% \mathrm{CI}=0.69$ to $0.89 ; \mathrm{p}=0.001)$. Patients with type $2 \mathrm{DM}$ with comorbid depression had a 0.45 times chance of having a good quality of life compared to type $2 \mathrm{DM}$ patients without comorbid depression $(\mathrm{aOR}=0.45 ; 95 \% \mathrm{CI}=0.28$ to 0.73 ; $\mathrm{p}=0.001$ ).

Conclusion: Patients with type $2 \mathrm{DM}$ without complications of neuropathy and without comorbid depression have a better quality of life than patients with type 2 DM with complications of neuropathy and comorbid depression.

Keywords: diabetes melitus, diabetic neuropathy, depresssion, quality of life

\section{Correspondence:}

Rofana Aghniya. Masters Program in Public Health, Universitas Sebelas Maret. Jl.Ir. Sutami 36A, Surakarta 57126, Central Java. Email: rofanaaa@gmail.com. Mobile:085523528340.

Cite this as:

Aghniya R, Murti B, Tamtomo DG (2020). Meta-Analysis: The Effect of Neuropatic Complications and Depression Commorbidity on the Quality of Life of Patients with Type 2 Diabetes. J Epidemiol Public Health. 05(03): 359-371. https://doi.org/10.26911/jepublichealth.2020.05.03.10.

(c) (i) (2) Journal of Epidemiology and Public Healthis licensed under a Creative Commons Journal of Epidemiology and Public Healthis licensed under a Crea
Attribution-NonCommercial-ShareAlike 4.o International License.

BACKGROUND

Diabetes mellitus is a group of metabolic diseases characterized by hyperglycemia due to impaired insulin secretion, insulin action or both. Chronic hyperglycemia in diabetes is associated with long-term 
Aghniya et al./ Neuropatic Complications and Depression Commorbidity on the Quality of Life

damage, dysfunction and abnormalities of organs, especially the eyes, kidneys, nerves, heart and blood vessels (ADA, 2014).

The prevalence of diabetes for several decades has increased dramatically due to the continuous increase in the incidence of Type 2 diabetes (Danaei et al., 2011). According to data from the World Health Organization (WHO), statistically $>422$ million adults suffered from diabetes in 2014 (Zhou et al., 2016). This increase is expected to continue to grow. The International Diabetes Federation predicts that this figure will increase to 642 million by 2040 (Ogurtsova et al., 2017).

Individuals with diabetes have a lower quality of life than without diabetes in the same age group (Grandy \& Fox, 2008) and their quality of life decreases with disease progression and complications (Wexler et al., 2006).

Iglay et al. (2016) stated that $97.5 \%$ of diabetic patients had at least 1 comorbidity and $88.5 \%$ had 2 comorbidities, this increase in prevalence increases with increasing patient age. Apart from complications, comorbidity in diabetic patients also affects the patient's quality of life (Landman et al., 2010).

A study conducted by Adriaanse et al. (2015) showed a negative association between the number of comorbidities suffered by DM patients and low quality of life values both physically $(\mathrm{r}=-0.51)$ and mentally $(r=-0.17) \quad(p<0.001)$. Another study states that the comorbidity of neuropathy, depression and hypertension in DM patients is significantly associated with a lower quality of life for type 2 DM patients (Schram et al., 2009; Landman et al., 2010).

Diabetic neuropathy is one of the microvascular complications which is the main cause of foot ulcers and leg amputation in DM patients. As the prevalence of
DM increases, the prevalence rate of neuropathic complications increases.

Happich et al. (2008) in their study found that patients with complications of diabetic neuropathy had a lower quality of life than DM patients without neuropathic complications in both the physical and mental components. This decline in quality of life will continue with the severity of the patient's neuropathy.

Depression is the most common psychiatric disorder that occurs more frequently in diabetic patients than in the general population (Anderson et al., 2001). Diabetic patients with depression have a double risk of death than those without depression (Nouwen et al., 2010). A metaanalysis combining the results of 10 studies reported that the mortality rate for depressed diabetic patients was 1.5 times higher than that of non-depressed diabetic patients (Park et al., 2013).

The cause of depression can be due to lack of motivation, excessive worry about possible complications that may arise, changes in diet and lifestyle and due to lack of family support (Penckofer et al., 2012). Patients with comorbid depression are prone to disobeying doctor's instructions, not taking medication regularly and not doing a diet so that blood sugar levels become uncontrolled. This of course will result in complications and decreased quality of life (Chew et al., 2015).

Research conducted in the USA states that diabetes patients with major depression tend to have lower quality of life scores than type 2 diabetes mellitus patients without depression both in mental aspects $(\mathrm{OR}=4.36 ; 95 \% \mathrm{CI}=3.33$ to 5.72$)$ and physical (OR= 9.77; $95 \% \mathrm{CI}=7.81$ to 12.22$)$ and had a lower life satisfaction rate $(\mathrm{OR}=$ $0.12 ; 95 \% \mathrm{CI}=0.07$ to 0.14 ) (Egede et al., 2010).

Various studies have been carried out 
Aghniya et al./ Neuropatic Complications and Depression Commorbidity on the Quality of Life

with mixed results around the world, but further analysis is needed to reach more convincing conclusions. Therefore, the researcher was interested in analyzing using a systematic approach to relevant studies by conducting a meta-analysis to identify the magnitude of the influence of each neuropathic complication and comorbidity of depression on the quality of life of patients with type 2 DM.

\section{SUBJECTS AND METHOD}

\section{Study Design}

This research is a systematic review and meta-analysis carried out by following the PRISMA flow diagram. The process of searching for articles is carried out by searching through journal databases which include: Google Scholar, PubMed, Springer Link, Science Direct, Scopus and ProQuest. Key words used include: "DM and Quality of Life" "Neuropathy and Quality of Life" "complication neuropathy and DM" "comorbidity depression and DM" "neuropathy and diabetes mellitus", "depression and diabetes mellitus", "neuropathy and quality of life and DM ", depression and quality of life and DM ", " neuropathy and quality of life and DM and cross sectional study ", depression and quality of life and DM and cross sectional study", "neuropathy and quality of life and DM and adjusted odds ratio "," depression and quality of life and DM and adjusted odds ratio ".

\section{Inclusion Criteria}

Downloaded article is a full-text article with an appropriate title relating to neuropathic comorbidity and depression comorbidity in type 2 diabetes mellitus. The article is in English and is a cross-sectional observational study design. His article used a multivariate analysis with results that reported a value (aOR) Adjusted Odds Ratio and quality of life outcomes for type $2 \mathrm{DM}$ patients.

\section{Exclusion Criteria}

The exclusion criteria in this study were articles conducted with a randomized controlled trial (RCT) study design, a quasi experiment, a protocol study and a pilot study. The articles are those that use languages other than English and the articles are those that do not use multivariate analysis.

\section{Operational Definition of Variable}

Diabetic Neuropathy is the presence of symptoms and / or signs of nerve dysfunction in diabetics without any other cause besides Diabetes Mellitus (DM) (after exclusion of other causes).

Depression is a disorder of feelings of heart, interest or excitement in daily activities accompanied by other findings such as sleep disturbances and changes in appetite. The instrument used to measure the level of depression used the Beck Depression Inventory-II (BDI-II) and other instruments that had their validity and reliability tested.

Quality of Life is an individual's perception of their position in life and the cultural context and value system in which they live and in relation to individual goals, expectations, standards and concerns.

Diabetes mellitus is a metabolic disease characterized by hyperglycemia due to impaired insulin secretion, insulin action or both.

\section{Instruments}

The research stages followed the PRISMA flow diagram and the assessment of the quality of research articles, using the Critical Appraisal Check List For Study from the Center for Evidence Based Management, (2014) for a cross-sectional study.

\section{Data Analysis}

The data analysis process in this study was carried out using the Review Manager application (RevMan 5.3), to determine the effect size and heterogeneity of the study. The results of meta-analysis data process- 
ing are presented in the form of a forest plot and a funnel plot.

\section{RESULTS}

The process of searching for articles on an electronic data base according to PRISMA flow diagrams can be seen in Figure 1.

Fifteen articles out of 1,564 were included in this study with a total of 53,462 patients as subjects. Articles from 5 continents. 6 studies came from the Asian conti- nent (Japan, Iran, Singapore, Korea, China and Nepal), 4 studies from the European continent (Norway and 3 United Kingdom), 2 studies from the African continent (Uganda and Nigeria), 2 studies from the North American continent (Brazil) and 1 study from the continent of South America (USA). Furthermore, the researchers conducted an assessment of the quality of the articles (Table 1) and summarized the contents of the articles in table 2.

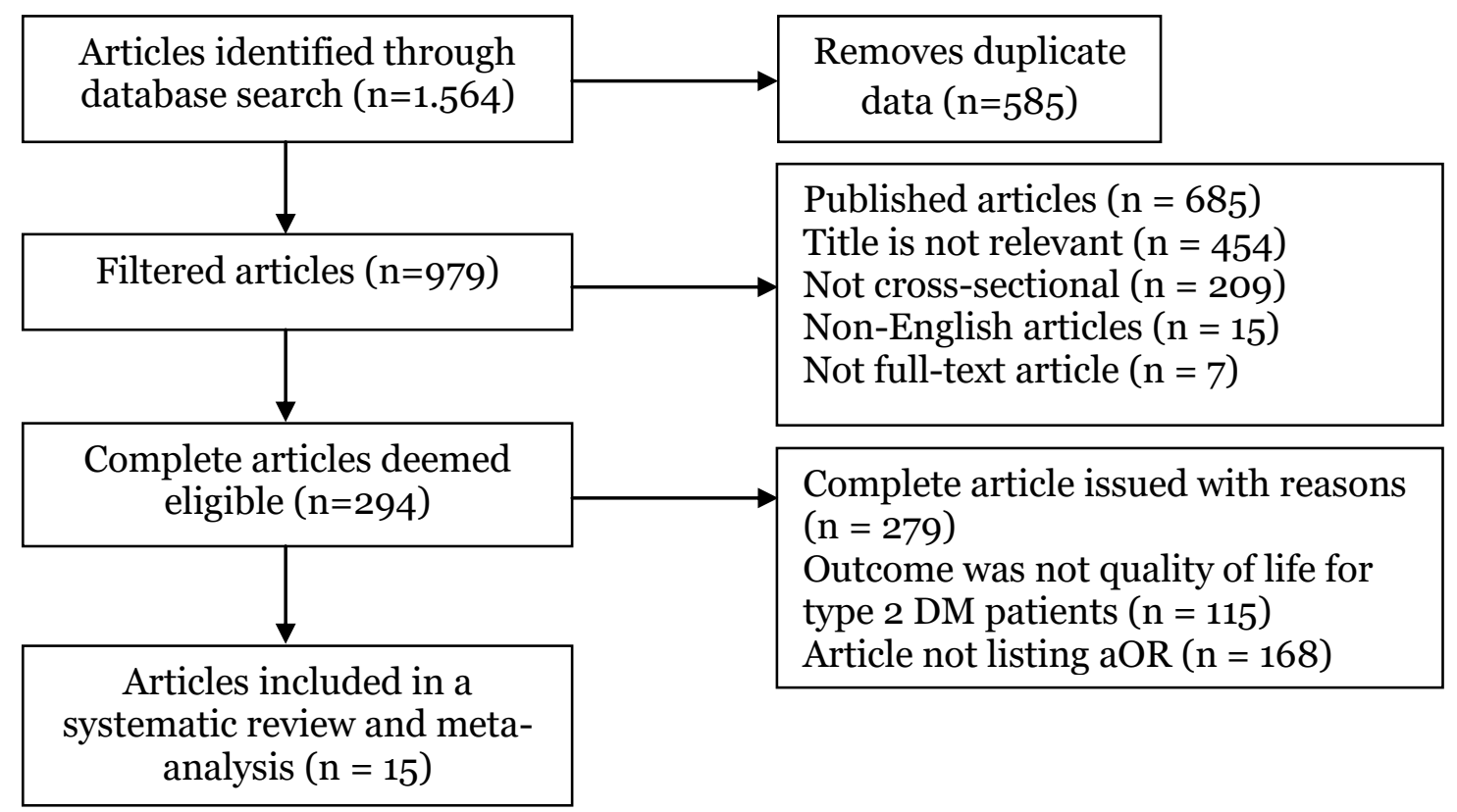

\section{Figure 1. PRISMA flow diagram}

\section{Effect of neuropathic complica- tions on quality of life}

There are 7 cross-sectional study used as a source of meta-analysis of the effect of neuropathic complications on the quality of life of Type 2 DM patients. These studies were conducted on 2 continents with 5 different countries, Iran, Japan, Norway, Singapore, Uganda, and the UK.

\section{a. Forest Plot}

Figure 2 shows that the aOR value is 0.78 (95\% CI= 0.69 to 0.89 ), which means that type 2 diabetes mellitus patients with neuropathic complications have a 0.78 times likelihood of having a good quality of life compared to type $2 \mathrm{DM}$ patients without neuropathic complications $(\mathrm{aOR}=0.78$; 95\% CI= 0.69 to $0.89 ; \mathrm{p}=0.001)$. The heterogeneity of the research data shows $\mathrm{I}^{2}=$ $73 \%$, which means that the distribution of data can be stated as heterogeneous (random effect model). 
Aghniya et al./ Neuropatic Complications and Depression Commorbidity on the Quality of Life

\begin{tabular}{|c|c|c|c|c|c|c|c|c|}
\hline Study or Subgroup & log[Odds Ratio] & SE & Weight & $\begin{array}{c}\text { Odds Ratio } \\
\mathrm{IV}, \text { Random, } 95 \% \mathrm{Cl}\end{array}$ & & $\begin{array}{r}\text { Odds } \\
\text { IV, Rando }\end{array}$ & $\begin{array}{l}\text { Ratio } \\
\mathrm{m}, 95 \% \mathrm{Cl}\end{array}$ & \\
\hline Abedini et al 2020 & -0.844 & 1.0048 & $0.4 \%$ & $0.43[0.06,3.08]$ & & 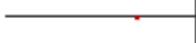 & & \\
\hline Akena et al 2015 & -0.5798 & 0.1978 & $7.7 \%$ & $0.56[0.38,0.83]$ & & $\rightarrow$ & & \\
\hline Currie et al 2006 & -0.1744 & 0.1004 & $17.3 \%$ & $0.84[0.69,1.02]$ & & $\Rightarrow$ & & \\
\hline Davies et al 2006 & -0.5108 & 0.093 & $18.4 \%$ & $0.60[0.50,0.72]$ & & $\rightarrow$ & & \\
\hline Riandini et al 2017 & -0.9943 & 1.7493 & $0.1 \%$ & $0.37[0.01,11.41]$ & & & & \\
\hline Sakamaki et al 2006 & -0.1625 & 0.0183 & $29.8 \%$ & $0.85[0.82,0.88]$ & & - & & \\
\hline Solli et al 2010 & -0.0834 & 0.0464 & $26.2 \%$ & $0.92[0.84,1.01]$ & & 耳 & & \\
\hline Total $(95 \% \mathrm{Cl})$ & & & $100.0 \%$ & $0.78[0.69,0.89]$ & & $\bullet$ & & \\
\hline \multicolumn{5}{|c|}{$\begin{array}{l}\text { Heterogeneity: } \text { Tau }^{2}=0.01 ; \mathrm{Chi}^{2}=22.01, \mathrm{df}=6(\mathrm{P}=0.001) ; \mathrm{I}^{2}=73 \% \\
\text { Test for overall effect: } Z=3.84(P=0.0001)\end{array}$} & 0.01 & ${ }_{\text {Neuropati }}^{0.1}$ & $\begin{array}{c}10 \\
\text { Tidak Neuropati }\end{array}$ & 100 \\
\hline
\end{tabular}

Figure 2. Forest plot of the effect of neuropathy complications on quality of life

\section{b. Funnel Plot}

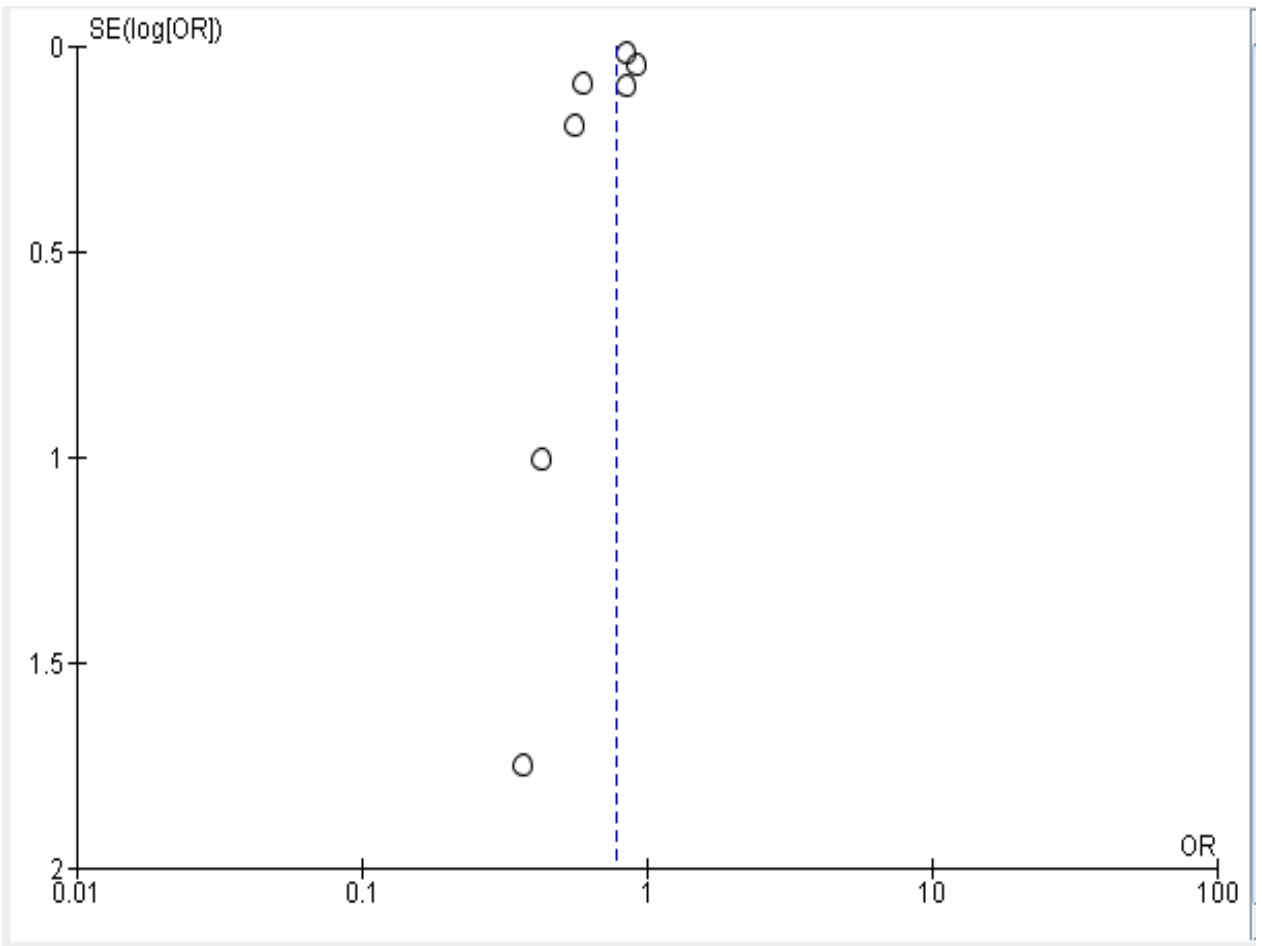

Figure 3. Funnel plot of the effect of neuropathic complications on quality of life

Figure 3 shows that the distribution of the research between the right and left plots is not symmetrical where there are 3 plots on the right and 4 plots on the left so it can be concluded that there is a publication bias in this study. The plot on the left of the graph appears to have a standard error between 0.2 and 1.7, and the plot on the right has a standard error between 0 and 0.2 .

\section{Effects of comorbid depression on quality of life}

There are 9 articles of cross-sectional observational study used as a source of meta-analysis of the effect of comorbid depression on the quality of life of type 2 DM patients with a range of studies between 2007 and 2016 which were conducted on 4 continents with 8 different 
countries, namely Brazil, China, Korea, Nepal, Nigeria, Uganda, UK, and USA.

\section{a. Forest Plot}

Figure 4 shows that patients with type 2 diabetes mellitus with comorbid depression have a 0.45 times likelihood of having a good quality of life compared to type 2 dia- betes mellitus patients without comorbid depression $(\mathrm{aOR}=0.45 ; 95 \% \mathrm{CI}=0.28$ to $0.73 ; \mathrm{p}=0.001)$. The heterogeneity of the research data shows $\mathrm{I}^{2}=91 \%$, which means that the distribution of data can be stated as heterogeneous (random effect model).

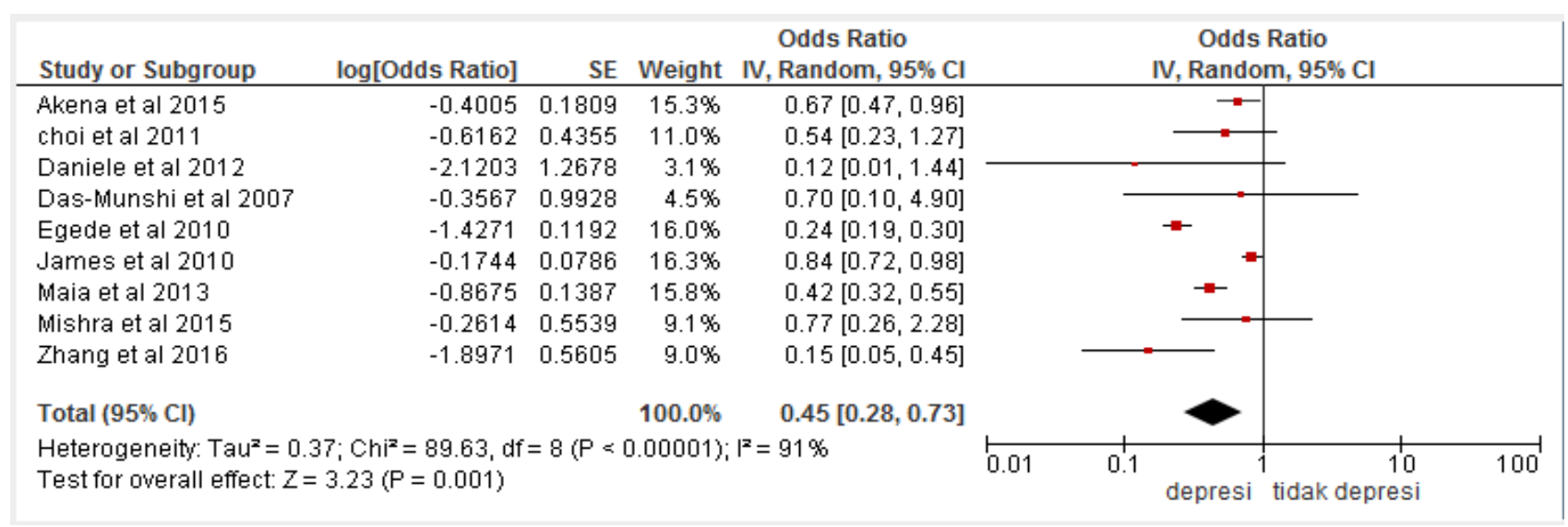

Figure 4. Forest plot of the effect of comorbid depression on quality of life

\section{b. Funnel Plot}

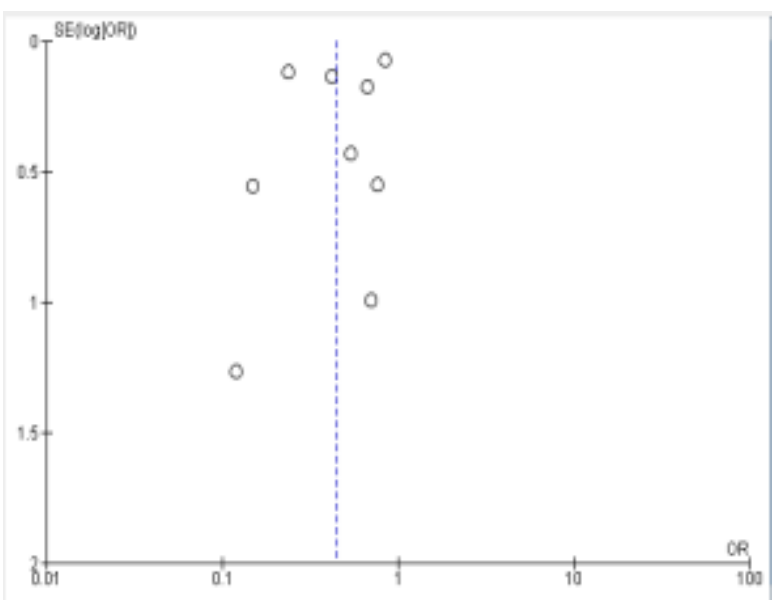

Figure 5. Funnel plot of the effect of comorbid depression on quality of life

Figure 5 shows that the distribution of the research between the right and left plots is not symmetrical where there are 5 plots on the right and 4 plots on the left so it can be concluded that there is a publication bias in this study. The plot on the right of the graph appears to have a standard error between 0.1 and 1, and the plot on the left has a standard error between 0.1 and 1.3. 
Table 2. Summary of sources of the effect of neuropathic complications and comorbid depression on the quality of life of type 2 DM patients

\begin{tabular}{|c|c|c|c|c|c|}
\hline $\begin{array}{l}\text { Author and } \\
\text { Year }\end{array}$ & Country & $\begin{array}{l}\text { Sample } \\
\text { size }\end{array}$ & Intervention (I) and Comparison (C) & Outcome & $\begin{array}{c}\text { Effect } \\
\text { OR (95\% CI) }\end{array}$ \\
\hline $\begin{array}{l}\text { James et al., } \\
(2010)\end{array}$ & Nigeria & 200 & $\begin{array}{l}\text { I: comorbid depression } \\
\text { C: without comorbid depression }\end{array}$ & Quality of life & $0.84(0.72,0.98)$ \\
\hline $\begin{array}{l}\text { Mishra et al., } \\
\text { (2015) }\end{array}$ & Nepal & 157 & $\begin{array}{l}\text { I : komorbiditas depresi } \\
\text { C : tanpa komorbiditas depresi }\end{array}$ & Quality of life & $0.77(0.26,2.28)$ \\
\hline $\begin{array}{l}\text { Akena et al., } \\
(2015)\end{array}$ & Uganda & 437 & $\begin{array}{l}\text { I: neuropathic complications and comorbid depression } \\
\text { C: without complications of neuropathy and comorbid } \\
\text { depression }\end{array}$ & Quality of life & $0.67(0.47,0.96)$ \\
\hline Maia et al., (2013) & Brazil & 210 & $\begin{array}{l}\text { I: comorbid depression } \\
\text { C: without comorbid depression }\end{array}$ & Quality of life & $0.42(0.32,0.55)$ \\
\hline $\begin{array}{l}\text { Egede } \\
(2010)\end{array}$ et al., & USA & 16,754 & $\begin{array}{l}\text { I: comorbid depression } \\
\text { C: without comorbid depression }\end{array}$ & Quality of life & $0.24(0.19,0.30)$ \\
\hline $\begin{array}{l}\text { Daniele et al., } \\
\text { (2012) }\end{array}$ & Brazil & 200 & $\begin{array}{l}\text { I: comorbid depression } \\
\text { C: without comorbid depression }\end{array}$ & Quality of life & $0.12(0.01,1.44)$ \\
\hline $\begin{array}{l}\text { Zhang et al., } \\
(2016)\end{array}$ & China & 944 & $\begin{array}{l}\text { I: comorbid depression } \\
\text { C: without comorbid depression }\end{array}$ & Quality of life & $0.15(0.05,0.45)$ \\
\hline Choi et al., (2011) & Korea & 14,441 & $\begin{array}{l}\text { I: comorbid depression } \\
\text { C: without comorbid depression }\end{array}$ & Quality of life & $0.54(0.23,1.27)$ \\
\hline $\begin{array}{l}\text { Das-Munshi et al., } \\
\text { (2007) }\end{array}$ & UK & 8,580 & $\begin{array}{l}\text { I: comorbid depression } \\
\text { C: without comorbid depression }\end{array}$ & Quality of life & $0.70(0.10,4.90)$ \\
\hline Solli et al., (2010) & Norway & 1,000 & $\begin{array}{l}\text { I: comorbid depression } \\
\text { C: without comorbid depression }\end{array}$ & Quality of life & $0.92(0.84,1.01)$ \\
\hline $\begin{array}{l}\text { Currie } \\
(2006)\end{array} \quad$ et al., & UK & 1,298 & $\begin{array}{l}\text { I: neuropathic complications } \\
\text { C: without neuropathy complications }\end{array}$ & Quality of life & $0.84(0.69,1.02)$ \\
\hline $\begin{array}{l}\text { Riandini et al., } \\
(2017)\end{array}$ & Singapore & 80 & $\begin{array}{l}\text { I: neuropathic complications } \\
\text { C: without neuropathy complications }\end{array}$ & Quality of life & $0.37(0.01,11.41)$ \\
\hline $\begin{array}{l}\text { Davies et al., } \\
(2006)\end{array}$ & UK & 8,531 & $\begin{array}{l}\text { I: neuropathic complications } \\
\text { C: without neuropathy complications }\end{array}$ & Quality of life & $0.60(0.50,0.72)$ \\
\hline $\begin{array}{l}\text { Abedini } \\
(2020)\end{array}$ & Iran & 300 & $\begin{array}{l}\text { I: neuropathic complications } \\
\text { C: without neuropathy complications }\end{array}$ & Quality of life & $0.43(0.06,3.08)$ \\
\hline $\begin{array}{l}\text { Sakamaki et al., } \\
(2006)\end{array}$ & Japan & 330 & $\begin{array}{l}\text { I: neuropathic complications } \\
\text { C: without neuropathy complications }\end{array}$ & Quality of life & $0.85(0.82,0.88)$ \\
\hline
\end{tabular}


Aghniya et al./ Neuropatic Complications and Depression Commorbidity on the Quality of Life

\section{Table 1.Research Quality Assessment (Critical Appraisal for Cross-Sectional Study)}

Publication (Author and Year)

\begin{tabular}{|c|c|c|c|c|c|c|c|c|c|c|c|c|c|c|c|}
\hline $\begin{array}{c}\text { Item of } \\
\text { evaluation }\end{array}$ & $\begin{array}{c}\text { Currie et } \\
\text { al. } \\
(2006)\end{array}$ & $\begin{array}{c}\text { Davies et } \\
\text { al. } \\
(2006)\end{array}$ & $\begin{array}{l}\text { Sakama- } \\
\text { ki et al. } \\
(2006)\end{array}$ & $\begin{array}{l}\text { Solli et } \\
\text { al } \\
(2010)\end{array}$ & $\begin{array}{l}\text { Akena } \\
\text { et al } \\
(2015)\end{array}$ & $\begin{array}{l}\text { Riandi } \\
\text { ni et al } \\
(2017)\end{array}$ & $\begin{array}{l}\text { Abedini } \\
\text { et al } \\
(2020)\end{array}$ & $\begin{array}{l}\text { Das- } \\
\text { Munshi } \\
\text { et al } \\
(2007)\end{array}$ & $\begin{array}{c}\text { Egede } \\
\text { et al } \\
(2010)\end{array}$ & $\begin{array}{c}\text { James } \\
\text { et al } \\
(2010)\end{array}$ & $\begin{array}{c}\text { Choi et } \\
\text { al } \\
(2011)\end{array}$ & $\begin{array}{c}\text { Daniele } \\
\text { et al } \\
(2012)\end{array}$ & $\begin{array}{c}\text { Maia et } \\
\text { al } \\
(2013)\end{array}$ & $\begin{array}{l}\text { Mishra } \\
\text { et al } \\
(2015)\end{array}$ & $\begin{array}{c}\text { Zhang et } \\
\text { al. } \\
(2016)\end{array}$ \\
\hline $\begin{array}{l}\text { Relevance of goals } \\
\text { and problems }\end{array}$ & 1 & 1 & 1 & 1 & 1 & 1 & 1 & 1 & 1 & 1 & 1 & 1 & 1 & 1 & 1 \\
\hline $\begin{array}{l}\text { Relevance of } \\
\text { methods and } \\
\text { problems }\end{array}$ & 1 & 1 & 1 & 1 & 1 & 1 & 1 & 1 & 1 & 1 & 1 & 1 & 1 & 1 & 1 \\
\hline Sample adequacy & 1 & 1 & 1 & 1 & 1 & o & 1 & 1 & 1 & o & 1 & 1 & 1 & 1 & 1 \\
\hline Sample validity & 1 & 1 & 1 & 1 & 1 & 1 & 1 & 1 & 1 & 1 & 1 & o & 1 & 1 & 1 \\
\hline $\begin{array}{l}\text { Cases and controls } \\
\text { were comparable }\end{array}$ & o & 1 & 1 & 1 & 1 & 1 & 1 & 1 & 1 & 1 & 1 & 1 & o & 1 & 1 \\
\hline There is no bias & 1 & 1 & 1 & 1 & 1 & 1 & 1 & 1 & 1 & 1 & 1 & 1 & 1 & 1 & 1 \\
\hline $\begin{array}{l}\text { Information data } \\
\text { tracking }\end{array}$ & 1 & 1 & 1 & 1 & 1 & 1 & 1 & o & 1 & 1 & 1 & 1 & 1 & 1 & 1 \\
\hline $\begin{array}{l}\text { Analysis of } \\
\text { relevant and valid } \\
\text { data } 1\end{array}$ & 1 & o & 1 & 1 & 1 & 1 & 1 & 1 & 1 & 1 & 1 & 1 & 1 & 1 & 1 \\
\hline $\begin{array}{l}\text { Relevance Effect } \\
\text { Size }\end{array}$ & 1 & 1 & 1 & 1 & 1 & 1 & 1 & 1 & 1 & 1 & 1 & 1 & 1 & 1 & 1 \\
\hline Reporting 95\% CI & 1 & 1 & 1 & 1 & 1 & 1 & 1 & 1 & 1 & 1 & 1 & 1 & 1 & 1 & 1 \\
\hline $\begin{array}{l}\text { Confounding } \\
\text { factors reported }\end{array}$ & 1 & 1 & 1 & 1 & 1 & 1 & 1 & 1 & 1 & 1 & o & 1 & 1 & 1 & 1 \\
\hline $\begin{array}{l}\text { The results are } \\
\text { applied to } \\
\text { research }\end{array}$ & 1 & 1 & 1 & 1 & 1 & 1 & 1 & 1 & 1 & 1 & 1 & 1 & 1 & 1 & 1 \\
\hline Total & 11 & 11 & 12 & 12 & 12 & 11 & 12 & 11 & 12 & 11 & 11 & 11 & 11 & 12 & 12 \\
\hline
\end{tabular}

Note:

Yes $=1$

No $=0$ 
Aghniya et al./ Neuropatic Complications and Depression Commorbidity on the Quality of Life

\section{DISCUSSION}

This systematic review and meta-analysis study raised the theme of the effect of neuropathic complications and comorbid depression on the quality of life of patients with type 2 diabetes mellitus. in which studies did not control for confounding factors.

Confounding factors affect the relationship or effect of exposure to the occurrence of disease estimated (estimated) by the study is not the same as the relationship or effect that actually occurs in the target population, aka invalid (incorrect) study results (Murti, 2018).

This systematic review and metaanalysis study used a study that controlled for confounding factors using multivariate analysis and the statistical result reported was the adjusted odds ratio (aOR). The combined estimates of the association of neuropathic complications and comorbid depression on quality of life were processed using the RevMan 5.3 application using the random-effects models method. This method is used to analyze data in the form of: rate, time-time-to-event, hazard ratio, ordinal scale, adjusted estimate, difference of mean ratio of mean (Annulus 2019). The results of the systematic review and metaanalysis of this study are presented in the form of forest plots and funnel plots.

The funnel plot shows the relationship between the effect measure of the study and the sample size of the various studies studied, which can be measured in a variety of different ways (Murti, 2018). The funnel plot can be assessed from the asymmetry of the study, namely looking at the number of points on the right and left sides compared to the standard error and the balance of the number of studies on the right and left (Sterne et al., 2011).

\section{The effect of neuropathic compli- cations on the quality of life of type 2 DM patients}

Smith et al (2012) in their study found that out of 29 studies with 50,112 respondents had a DPN prevalence of $30 \%$ (95\% CI $=25$ to $34 \%)$. The prevalence of DPN in patients with type 2 diabetes mellitus was greater than in patients with type 1 diabetes (pooled prevalence $=31.5 \%$, 95\% CI $=24.4$ to $38.6 \%$ and pooled prevalence $=17.5 \%$, 95\% CI 18 to $30.2 \%)$.

Benbow et al (1998) had previously conducted a study on the relationship between DPN and the quality of life of type 2 DM patients in the UK and concluded that patients with neuropathic complications had a significantly higher Nottingham Health Profile (NHP) score than DM patients without neuropathy in $5 / 6$ domains (p $<0.001)$. In patients with peripheral neuropathy, there are changes in the sensory and motor nerves that result from damage to the autonomic nerves. Neuropathy of large nerve fibers causes numbness and ataxia, resulting in disruption of daily activities. Neuropathy of small nerve fibers often causes pain (Happich et al., 2007).

The study by Van Acker et al (2008) found that the prevalence of DPN was $43 \%$ (95\% CI $=12.1$ to 16.2 ) and was more common in type $2 \mathrm{DM}$ patients (50.8\%) than type 1 (25.6\%). The prevalence increases with age and duration of disease. Patients with DPN complications have a lower quality of life than DM patients without DPN with values $(\beta=-1.81, \mathrm{SE}=1.12, \mathrm{t}=-1.61, \mathrm{p}$ $=0.11)$ in the physical domain and values $(\beta$ $=1.11, \mathrm{SE}=1.30, \mathrm{t}=0.85, \mathrm{p}=0.39$ ).

Diabetic Peripheral Neuropathy (DPN) significantly has a strong association with decreased quality of life (Solli, 2010). The greatest decrease was in the physical function/mobility domain and the pain 
domain (Happich et al., 2007; Venkataraman et al., 2013).

\section{The effect of comorbid depression on the quality of life of type $2 \mathrm{DM}$ patients}

Diabetes patients often show psychopathological symptoms, including cognitive, emotional, anxiety and psychotic disorders and even personality disorders (Schram et al., 2009). The presence of chronic disease is highly correlated with the appearance of symptoms of depression and anxiety (Gerontoukou et al., 2015).

Unutzer et al (2000) in their study found that depressed patients had a lower quality of life than the group of patients with chronic diseases. The effect of depression and quality of life was obtained after controlling for other factors such as age and gender.

The role of various psychological factors is not only in the development and progression of DM but also how these factors affect patient compliance in carrying out medications and interventions. Depression, fear and a lack of health and social support can overwhelm the patient and affect the maintenance and control of blood glucose levels (Papelbaum et al., 2010). Poor glycemic control is associated with an increased risk of medical complications (Hanna et al., 2014).

A study in two outpatient clinics in Athens-Greece revealed that female gender is a risk factor for comorbid depression in patients with DM (Lyrakos et al., 2013). The prevalence of comorbid depression in T2DM patients is estimated to be $17.6 \%$ and higher in women with diabetes (23.8\%) compared to men (12.8\%) (Danhauer et al., 2019).

Hutter et al., (2009) conducted a study with the aim of knowing the relationship between mental disorders comorbidity and medical care and quality of life in patients with diabetes. By controlling for age and gender, it is concluded that the comorbidity of mental disorders is related to both psychosocial and physical aspects of the quality of life of patients with diabetes.

Various biopsychosocial factors also affect the level of depression and anxiety in type $2 \mathrm{DM}$ patients. Among them, social factors include marital status and work (Habtewold et al., 2016). In Greek patients with type $2 \mathrm{DM}$, older age, marital status and lower education were associated with health-related impaired quality of life (HRQOL) on at least one SF-36 subscale (Papadopoulos et al., 2007).

This is supported by Derakhshanpour et al (2015) which found that the average value and standard deviation of the quality of life of type 2 DM patients with depression was 50.7 and 14 and the quality of life for type $2 \mathrm{DM}$ patients without depression was 60.5 and 13.3 with $\mathrm{p}<0.001$. This means that DM patients with comorbid depression have a lower quality of life than DM patients without comorbid depression both in the domain of general health, overall quality of life, physical health, psychological health, environment and social relationships.

\section{AUTHOR CONTRIBUTION}

Rofana Aghniya, Bhisma Murti, and Didik Gunawan Tamtomo, collected the data, did meta analysis, interpreted the results, and wrote the paper.

\section{CONFLICT OF INTEREST}

There is no conflict of interest in this study.

\section{FUNDING AND SPONSORSHIP}

There was no external fund.

\section{ACKNOWLEDGEMENT}

Thank to open access online databases that provided articles. 
Aghniya et al./ Neuropatic Complications and Depression Commorbidity on the Quality of Life

\section{REFERENCE}

Adriaanse MC, Drewes HW, Van Der Heide I, Struijs JN, Baan C (2016). The impact of comorbid chronic conditions on quality of life in type 2 diabetes patients. Qual Life Res, 25: 175-182. https://doi.org/10.1007/s11136-0151061-0.

Anderson RJ, Freedland KE, Clouse RE, Lustman PJ (2001). The prevalence of comorbid depression in adults with diabetes: A meta-analysis. Diabetes Care, 24(6): 1069-1078. https://doi.org/10.2337/diacare.24.6.1069.

Anulus A, Murti B, Prasetya H (2019). Risk Factors of HIV among Male Military Personnels: A Meta Analysis. J Health Promot and Behav, 4(3): 178-188. doi:10.26911/thejhpb.2019.04.03.03.

Benbow SJ, Wallymahmed ME, Macfarlane IA (1998). Diabetic peripheral neuropathy and quality of life. QJM, 91(11), 733-737. https://doi.org/10.1093/qjmed/91.11.733.

Chew BH, Mohd-Sidik S, Shariff-Ghazali S (2015). Negative effects of diabetesrelated distress on health-related quality of life: An evaluation among the adult patients with type 2 diabetes mellitus in three primary healthcare clinics in Malaysia. Health Qual. Life Outcomes, 13(1). https://doi.org/10.1186/s12955-015-0384-4

Danaei G, Finucane MM, Lu Y, Singh GM, Cowan MJ, Paciorek CJ, Lin JK, Farzadfar F, Khang YH, Stevens GA, Rao M, Ali MK, Riley LM, Robinson CA, Ezzati M (2011). National, regional, and global trends in fasting plasma glucose and diabetes prevalence since 1980: Systematic analysis of health examination surveys and epidemiological studies with 370 country-years and $2 \cdot 7$ million participants. The Lancet, 378(9785): 31-40. https:-
//doi.org/10.1016/So140-6736(11)60679-X

Danhauer SC, Brenes GA, Levine BJ, Young L, Tindle HA, Addington EL, Wallace RB, Naughton MJ, et al. (2019). Variability in sleep disturbance, physical activity and quality of life by level of depressive symptoms in women with Type 2 diabetes. Diabetic Medicine, 36(9), 1149-1157. https://doi.org/10.1111/dme.13878.

Derakhshanpour F, Vakili MA, Farsinia M, Mirkarimi K (2015). Depression and quality of life in patients with type 2 diabetes. Iran Red Crescent Med J. 17(5): e27676. https://doi.org/10.5812/ircmj.17(5)2015.27676.

Egede LE, Grubaugh AL, Ellis C (2010). The effect of major depression on preventive care and quality of life among adults with diabetes. Gen Hosp. Psychiatry, 32(6): 563-569. https://doi.org/10.1016/j.genhosppsych.2010.08. 002.

Gerontoukou EI, Michaelidoy S, Rekleiti M, Saridi M, Souliotis K (2015). Investigation of anxiety and depression in patients with chronic diseases. Health Psychol, 3(2). https://doi.org/10.4081/hpr.2015.2123.

Grandy S, Fox KM (2008). EQ-5D visual analog scale and utility index values in individuals with diabetes and at risk for diabetes: Findings from the Study to Help Improve Early evaluation and management of risk factors Leading to Diabetes (SHIELD). Health Qual. Life Outcomes, 6: 18. https://doi.org/10.1186/1477-7525-6-18.

Habtewold TD, Alemu SM, Haile YG (2016). Sociodemographic, clinical, and psychosocial factors associated with depression among type 2 diabetic outpatients in Black Lion General Specialized Hospital, Addis Ababa, 
Aghniya et al./ Neuropatic Complications and Depression Commorbidity on the Quality of Life

Ethiopia: A cross-sectional study. BMC Psychiatry, 16(1): 1-7. https://doi.org/10.1186/s12888-016-0809-6.

Happich M, Breitscheidel L, Meisinger C, Ulbig M, Falkenstein P, Benter U, Watkins J (2007). Cross-sectional analysis of adult diabetes type 1 and type 2 patients with diabetic microvascular complications from a German retrospective observational study. Curr Med Res Opin. 23(6): 1367-1374. https://doi.org/10.1185/030079907X188215.

Happich M, John J, Stamenitis S, Clouth J, Polnau D (2008). The quality of life and economic burden of neuropathy in diabetic patients in Germany in 2002-Results from the diabetic microvascular complications (DIMICO) study. Diabetes Res. Clin. Pract. 81(2): 223-230. https://doi.org/10.1016/j.diabres.2008.03.019.

Hutter N, Scheidt-Nave C, Baumeister H (2009). Health care utilisation and quality of life in individuals with diabetes and comorbid mental disorders. Gen. Hosp. Psychiatry. 31(1), 33-35. https://doi.org/10.1016/j.genhosppsy ch.2008.09.008.

Iglay K, Hannachi H, Howie PJ, Xu J, Li X, Engel SS, Moore LM, Rajpathak S (2016). Prevalence and co-prevalence of comorbidities among patients with type 2 diabetes mellitus. Curr Med Res Opin. 32(7): 1243-1252. https://doi.org/10.1185/03007995.2016.1168 291.

Landman GWD, Van Hateren KJJ, Kleefstra N, Groenier KH, Gans ROB, Bilo HJG (2010). Health-related quality of life and mortality in a general and elderly population of patients with type 2 diabetes (ZODIAC-18). Diabetes Care, 33(11): 2378-2382. https://doi.org/10.2337/dc10-0979.
Lyrakos GN, Papazafiropoulou AK, Batistaki C, Xatziagelaki E, Damigos D, Tinas C, Mpakomitrou F, Bousboulas $\mathrm{S}$, Spinaris V (2013). 1412 - Differences in depression anxiety and stress among men and women with diabetes mellitus. European Psychiatry, 28(1): 1. https://doi.org/10.1016/s0924-9338(13)76450-2.

Murti B (2018). Prinsip dan Metode Riset Epidemiologi (Edisi V). Program Pascasarjana, Universitas Sebelas Maret. Surakarta: Bintang Fajar Offset.

Nouwen A, Winkley K, Twisk J, Lloyd CE, Peyrot M, Ismail K, Pouwer F (2010). Type 2 diabetes mellitus as a risk factor for the onset of depression: A systematic review and meta-analysis. Diabetologia, 53(12), 2480-2486. https://doi.org/10.1007/s00125-0101874-X

Ogurtsova K, da Rocha Fernandes JD, Huang Y, Linnenkamp U, Guariguata L, Cho NH, Cavan D, Shaw JE, Makaroff LE (2017). IDF Diabetes Atlas: Global estimates for the prevalence of diabetes for 2015 and 2040. Diabetes Res Clin Pract. 128: 40-50. https://doi.org/10.1016/j.diabres.2017.03.0 24.

Papadopoulos AA, Kontodimopoulos N, Frydas A, Ikonomakis E, Niakas D (2007). Predictors of health-related quality of life in type II diabetic patients in Greece. BMC Public Health, 7(1): 1-9. https://doi.org/10.1186/1471-2458-7-186.

Papelbaum M, Lemos HM, Duchesne M, Kupfer R, Moreira RO, Coutinho WF (2010). The association between quality of life, depressive symptoms and glycemic control in a group of type 2 diabetes patients. Diabetes Res. Clin. Pract. 89(3): 227-230. https://doi.org/10.1016/j.diabres.2010.05.024. 
Aghniya et al./ Neuropatic Complications and Depression Commorbidity on the Quality of Life

Park M, Katon WJ, Wolf FM (2013). Depression and risk of mortality in individuals with diabetes: A meta-analysis and systematic review. Gen. Hosp. Psychiatry. 35(3): 217-225. https://doi.org/10.1016/j.genhosppsych.2013. 01.006.

Penckofer S, Quinn L, Byrn M, Ferrans C, Miller M, Strange P (2012). Does glycemic variability impact mood and quality of life? Diabetes Technol. Ther. 14(4): 303-310. https://doi.org/10.1089/dia.2011.0191

Schram M, Baan C, Pouwer F (2009). Depression and quality of life in patients with diabetes: a systematic review from the European depression in diabetes (EDID) research consortium. Curr Diabetes Rev. 5(2): 112-9. https://doi.org/10.2174/157339909788166 828.

Smith BH, Torrance N (2012). Epidemiology of neuropathic pain and its impact on quality of life. Curr Pain Headache Rep. 16(3): 191-198. https://doi.org/10.1007/s11916-012-0256-0.

Solli O, Stavem K, Kristiansen IS (2010). Health-related quality of life in diabetes: The associations of complications with EQ-5D scores. Health Qual. Life Outcomes. 8: 18. https://doi.org/10.1186/1477-7525-8-18.

Sterne JAC, Sutton AJ, Ioannidis JPA, Terrin N, Jones DR, Lau J, Carpenter J, Rücker G (2011). Recommendations for examining and interpreting funnel plot asymmetry in meta-analyses of randomised controlled trials. BMJ. 343(7818). https://doi.org/10.1136/bmj.d4002.

Unützer J, Patrick DL, Diehr P, Simon G, Grembowski D, Katon W (2000).
Quality adjusted life years in older adults with depressive symptoms and chronic medical disorders. International Psychogeriatrics, 12(1): 15-33. https://doi.org/10.1017/s1041610200 o06177.

Van Acker K, Bouhassira D, De Bacquer D, Weiss S, Matthys $\mathrm{K}$, Raemen $\mathrm{H}$, Mathieu C, Colin IM (2009). Prevalence and impact on quality of life of peripheral neuropathy with or without neuropathic pain in type 1 and type 2 diabetic patients attending hospital outpatients clinics. Diabetes and Metabolism. 35(3): 206-213. https://doi.org/10.1016/j.diabet.2008.11.o 04.

Venkataraman K, Wee HL, Leow MKS, Tai ES, Lee J, Lim SC, Tavintharan S, Wong TY, Ma S, Heng D, Thumboo J (2013). Associations between complications and health-related quality of life in individuals with diabetes. Clin Endocrinol (Oxf). 78(6): 865-73. https://doi.org/10.1111/j.1365-2265.2012.04480.x.

Wexler DJ, Grant RW, Wittenberg E, Bosch JL, Cagliero E, Delahanty L, Blais MA, Meigs JB (2006). Correlates of health-related quality of life in type 2 diabetes. Diabetologia, 49(7): 14891497. https://doi.org/10.1007/s00125-006-0249-9.

Zhou B, Lu Y, Hajifathalian K, Bentham J, Di Cesare M, Danaei G, Bixby H, Cowan M, et al. (2016). Worldwide trends in diabetes since 1980: a pooled analysis of 751 population-based studies with 4.4 million participants. Lancet. $\quad 387(10027)$ : 1513-1530. https://doi.org/10.1016/So140-6736(16)oo618-8. 